\title{
Intermédialités
}

Histoire et théorie des arts, des lettres et des techniques

Intermediality

History and Theory of the Arts, Literature and Technologies

\section{The Coming Of Paper}

\section{Harold Adams Innis}

Numéro 17, printemps 2011

URI : https://id.erudit.org/iderudit/1005761ar

DOI : https://doi.org/10.7202/1005761ar

Aller au sommaire du numéro

Éditeur(s)

Revue intermédialités (Presses de l’Université de Montréal)

ISSN

1705-8546 (imprimé)

1920-3136 (numérique)

Découvrir la revue

Citer cet article

Innis, H. A. (2011). The Coming Of Paper. Intermédialités / Intermediality, (17), 232-255. https://doi.org/10.7202/1005761ar

\section{Résumé de l'article}

Dans la dernière décennie de sa vie, Harold. A. Innis a rassemblé un grand nombre d'écrits sous le titre : A History of Communications. L'extrait publié est pris dans la première section du chapitre IV, consacré à « l'avènement du papier ", qui commence avec son apparition en Chine " remontant à 105 apr. J.-C. » et se termine par la diffusion en Occident de la fabrication du papier au cours du Moyen Âge. Si l'industrie du papier et sa diffusion sont au coeur de la démarche d'Innis, il s'attache aussi particulièrement aux technologies conjointes de la production d'encre et de la xylographie ainsi qu'à

l'introduction des caractères mobiles. Il repère également les débuts de l'expansion du papier et de l'imprimerie dans ses différents contextes socio-culturels : la Chine, l'Inde, la Corée, le monde musulman, l'Europe. Après avoir montré en détail comment la fabrication du papier s'est implantée en Europe - en tant que formidable rival du parchemin -, Innis examine le lien entre le papier et un large spectre d'autres évolutions significatives, telles que le développement du crédit, le retour à l'Antiquité, la Réforme et la naissance de l’État moderne.
Ce document est protégé par la loi sur le droit d'auteur. L'utilisation des services d’Érudit (y compris la reproduction) est assujettie à sa politique d'utilisation que vous pouvez consulter en ligne.

https://apropos.erudit.org/fr/usagers/politique-dutilisation/ 


\title{
The Coming Of Paper*
}

\author{
HAROLD INNIS
}

A

fter experiments with various materials, the Chinese succeeded in producing paper from textiles as early as 105 A.D. Writing in China apparently began with the use of bamboo "tablettes" and continued to at least 126 A.D. It was followed by the production of paper from broken pieces of silk and finally from old rags. ${ }^{1}$

The heavy character of bamboo and the expensive character of silk led to the development of paper in 105 A.D. ${ }^{2}$ It spread to Japan from Korea and in the reign of Shotoku (572-623), paper was made from the bark of mûrier [paper mullbery]. In 703, four artists were mentioned in the code of Japan as charged with the manufacturer of paper. The industry was prosperous from 749 to 756 and in 770 the product used for the transcription of the sacred book of Buddha was of a high quality. In the period 806-809, the government established factories for the manufacture of paper. In the period $877-884$, taxes were imposed and paid in kind. The department of Minon became a great centre of the paper industry. By the end of the $9^{\text {th }}$ century a great variety of paper was produced and paper was used extensively. ${ }^{3}$

It rapidly displaced other writing materials and provided the background for an extensive printing industry. ${ }^{4}$ A large centralized state with its demands for a large number of documents and the spread of religion with the demands

* The following is an excerpt from the forthcoming book, Harold Innis's History of Communications, vol. 1 (accompanied by Innis's autobiographical memoir), edited by William J. Buxton, Michael Cheney, and Paul Heyer, to be published by Rowman and Littlefield.

1. Augustin Blanchet, Essai sur l'histoire du papier et de sa fabrication, Paris, Ernest Leroux, 1900, p. 6, 8, 20.

2. Thomas Francis Carter, The Invention of Printing in China and Its Spread Westward, New York, Columbia University Press, 1925, p. 1-2.

3. Blanchet, 1900, p. 20-22.

4. For an extensive discussion, see Carter, 1925. 
for charms brought an increase in the production of paper and the evolution of block printing. "At the end of the $6^{\text {th }}$ century, the imperial library [had] 37000 books [and] in the early part of the $8^{\text {th }}$ century 53951 books [and] 28469 [volumes] by recent authors." The T'ang Dynasty (618-907) marked the end of the long period of wars and under T'ai Tsung (626-49), a library of 200,000 volumes was collected. ${ }^{6}$

A hair brush was invented in the third century B.C., which "revolutionized printing and writing." The earliest paper was made of rag fibres and later sizing was added to make writing easier. Under Ts'in Shih Huang-Ti (246-209 B.C.), seals began to displace jade and "broken pieces of bamboo." In the T'ang Dynasty, seal impressions with ink on paper were developed into block prints. The use of paper was evident in the transition in the $5^{\text {th }}$ and $6^{\text {th }}$ centuries A.D. Ink had been developed from lampblack, probably in the $4^{\text {th }}$ or $5^{\text {th }}$ centuries or between 220 and 419 A.D. Its invention "has been ascribed to Wei Tang."

In the $10^{\text {th }}$ century, production reached a high standard under Li T"ing-kwei, “ink official," under Nan T'ang (937-975). The pine forests of An-hui Province became a recognized centre of the ink industry. ${ }^{9}$ Common and cheap inks were made from fir wood. Inks were put in small moulds for sale. ${ }^{10}$ Under the Sung Dynasty (960-1279), "vegetable, mineral and animal oils [were substituted] for pine lampblack." But lampblack was the chief substance. It was compounded with glutinous material to unite the "fine articles of carbon" and to "fix ink on paper with a brush." In "the Ming Dynasty (1368-1643) ink manufacturers appealed to notable artists for designs and pictorial [representation]." ${ }^{\prime \prime}$ Chinese ink made "a clean neat impression" and was indelible. It was not suited to "impressions from metal," as it formed "globules on the metal surface and made a rough impression." ${ }^{12}$

5. Frank B. Wiborg, Printing Ink: A History, with a Treatise on Modern Methods of Manufacture and Use, New York, Harper \& Brothers, 1926, p. 24.

6. Carter, 1925 , p. 28.

7. Lynn Thorndike, A Short History of Civilization, New York, F.S. Crofts \& Co., 1927, p. 261.

8. Carter, 1925, p. 5, 8-9, 24.

9. Wiborg, 1926, p. 27.

10. Carter, 1925, p. 25 .

11. Wiborg, 1926, p. 30-31, 38 and 51.

12. Carter, 1925, p. 25. 


\section{THE ROLE OF RELIGION}

Religion, as a result of the position of Confucius, had much less hold in China than India. "Lao- tsze was born in 605-604 B.C." ${ }^{3}$ He "advocated the surrender of the individual to the mysterious law and forces of the universe. Evil [followed] a bad act [and] a religion of magic, spirit and demon worship with miasma culture reinforced old customs and traditions. [...] From Taoism developed [an] elaborate system known as Fung Shui [which tended to] create an exclusive group [with] prejudice toward foreigners." 14 By 200 B.C., "the great ancient philosophers" belonged to the past. These followed "a thousand years of scholarship, textual comment" and art in religious works. "The edict against books was revoked in 191" B.C. and the emperor Wu-Ti "provided for the teaching of Confucianism and the use of examinations for office in 124 B.C. [...] Under the Han [Dynasty], Chou ideology was promptly restored, and perpetuated by examinations. The Han period produced scholarly comment [rather than] systems of thought."

Buddhism entered China around 200 A.D. when writing was well established and a formal philosophy and idea system had been worked out. It "brought an established tradition and manner of sculpture, [which reached] its culmination about 700 A.D." "15 The adoption of the Buddhist faith by Ashoka the Great (Asoka) in 250 A.D. meant replacement of "superstitious ceremonial law with moral law" and its identification with "the supreme power of the state. [...] Buddhism hardened into a system of traditional observances stifled by codes and forms and became [the] religion of [the] book, rather than of the living soul."16

Buddhism was introduced by Emperor Ming Ti in 65 A.D. and reached its peak from 400 to 700 A.D. ${ }^{17}$ Buddhist doctrine, like Buddhist art, aimed at "the mass of the population" rather than the courts, "which were best able to foster the highest aesthetic developments." Painting was associated with the literary tradition of Confucianism and officialdom, and sculpture, to a very important extent, with Buddhism, with the result that painting "lived longer than sculpture." After the persecution of 845 , Buddhism became "a plebeian religion" of the

13. Alfred Louis Kroeber, Configurations of Culture Growth, Berkeley, University of California Press, 1944, p. 67.

14. John Hopkins Denison, Emotion as the Basis of Civilization, New York, Charles Scribner's Sons, 1928, p. 116.

15. Kroeber, 1944, p. 67, 71-72, 274-275.

16. Denison, 1928, p. 150-152.

17. John Knight Shryock, The Origin and Development of the State Cult of Confucius: An Introductory Study, New York, The Century, 1932, p. 115. 
uneducated class - "a religion of numbers rather than quality." It never dominated China and was alternately "encouraged and persecuted." Sculpture had run its course by the $9^{\text {th }}$ century. It "ranked lower than painting," since it "[involved the] use of hands, and [savoured artisanship]." ${ }^{18}$ Painting, on the other hand, was a "full sister" to calligraphy and was regarded as a part of education, with "the hallmark of social status." The stroke, brush, ink, and paper or silk were common to painting and writing. "One-stroke writing" was introduced around 350 and transferred to painting about 450 . "Brush strength [was] the painter's highest virtue."

In Japan, writing was introduced in 405 and Buddhism in 522. By 594, the Emperor ordered the use of images and the construction of a temple "in every province [and] in 685, Buddhism was made a state religion." It grafted itself on the national religion and became an ally of social custom concerned mainly with the future life. Every act of life bore results in future reincarnations. ${ }^{19}$ Japan had cultivated a new set of feelings by "elaborate emotional cultures." Its particular characteristic was the control of the group by itself-each regulating and enforcing its "own customs and rules." Emotion expressed itself in forms "defined by custom." The family was all and "the individual [counted] for nothing." The clan culture held together a powerful family culture. Since "the successful clan claimed the Sun-Goddess [...] as [its] first ancestor, [...] she became the chief national god." ${ }^{20}$ A culture with "ferocity of detail" was enforced by the "feeling and will of the people [and] not by law. [...] The mainspring [of the culture of the Samurai] was the belief that the spirits of ancestors lived to watch and help them."21

Japan's first idea of art was Buddhistic-all art served religion. "Alone of all [the] great plastic arts, Japanese sculpture [made] practically no use of stone." In China and Japan, "painting climaxed later than sculpture and far outlived it." In Japan, "fine art and religion [were] divorced about 1300," but sculpture was never wholly free from Buddhism and died out with "aesthetic-religious impulses. [...] China stripped off formal aristocracy and did not overvalue preciosity and refinement," but in Japan, culture was dissipated "from the entourage of the sacred Emperor. Writing was adopted by the court [and] literature was the [creation] of princes, nobles, and court ladies who could read." In the Tokugawa shogunate,

18. Kroeber, 1944, p. 72, 260, 269, 275-276.

19. Ibid., p. 176, 269, 276, 332 .

20. Denison, 1928, p. 159-161,163-164.

21. Ibid., p. 167, 169, 173 . 
"peace, industry, trade, and cities grew, and with them, wealthy commoners, educated plebeians, [and] true bourgeoisie." There were new novels and drama, "new verse forms, [and] new painting and, color blocks." An "isolated people" changes culture, but produces little to be passed on to others. ${ }^{22}$

\section{THE INDIAN SUBCONTINENT}

Like Latin and Greek, Sanskrit was very synthetic. "Aryans occupied the upper part of the Indus Valley [at] some time before 1500 B.C. The earliest records of the Indo-Aryan language [are] preserved in the Vedas," a religious literature based on an oral tradition independent of writing. Sanskrit spread in the south of India as the language of religion and law, but the Dravidian languages were not displaced. The language of the educated spread with freedom of movement up and down the rivers and was accompanied by linguistic change. The language of the Vedas was changed through "theological treaties called Brahmanas and philosophical Upanishads to [a] perfected form of classical Sanskrit," which became the standard book language of ancient India. ${ }^{23}$ The Vedas were regarded "as the source of religion and the basis of [the] social fabric." As a "[result] of a culture based on a book, which [was] fundamental in all great civilizations," reverence was created by religion. "The culture of India was directed toward [the stabilization] of certain groups." The Brahmins were priests or teachers. "Man [progressed] by deepening relations rather than by broadening or changing them." 24 "By 500 B.C. the Aryan tongue had spread down the Ganges Valley, [but with changes] in the traditional language of literature used by [the] Brahmins, [and by] persons educated by them and in the speech of the mass of people including women of the higher castes." Guatama Buddha, the founder of Buddhism, flourished about 500 B.C. and "the earliest surviving scriptures [were] written in [the] form of Prākrit [or natural language]."25 "In India, philosophy was more deeply rooted, influential and tenacious" than elsewhere. The drama was never written or spoken in the vernacular. "The Sanskrit literary theatre was a [conscious] artificial production by and for a cultivated class-a sort of court drama." In China and India, literature was without political and national stirrings and the "mass of the population [does] not participate in government

22. Kroeber, 1944, p. 277, 339, 341, 679-680.

23. Alfred Cooper Woolner, Languages in History and Politics, London, Oxford University Press, 1938, p. 68-70, 77-78.

24. Denison, 1928, p. 124, 132, 135.

25. Woolner, 1938, p. 77-78. 
or literature." In India, Buddhism was less permanent than Brahmanism, but outside India, Buddhism became a world religion. ${ }^{26}$

Religion penetrated other cultures with dependence on less refined types of representation, such as images and sculpture. Buddhism made its impact on China largely as a result of the elaborate refinements of Confucianism in the upper classes, but it secured a less firm hold because of its limitations as to language. The limitations of language permitted its incursion, but prevented its domination. "Semipopular currents, developing below the surface in science, literature, and art, were checked by the [...] classical scholarship and traditionalism of the Sungs, until [the latter was disputed when] they poured forth vigorously under [a] new political and social order." ${ }^{27}$

\section{EARLY BLOCK PRINTING AND RELIGION}

Ink rubbings were taken from stone inscriptions and, in turn, inked impressions from wood were used to make books. "Stone classics were set up [from] 836 to 841 " and "authorized rubbings" from stone inscriptions were made. By the $9^{\text {th }}$ century, stones were prepared for the purpose of rubbing and "single sheets and roll-books were printed from specially prepared blocks of stone." Buddhism emphasized stamped charms and reduplication. In the $10^{\text {th }}$ century, the greatest activity was in duplicating processes and the emphasis was on rubbing rather than inscription. The "union of the Buddhist block print and Confucian rubbing produced the great official block printing [period] when China's great literature was printed. [...] Confucian classics cut in wood marked the beginning of large scale block printing, [and] Buddhist prints gave the idea of cutting [inscriptions] in reverse, providing a new technique for taking the rubbing." 28

"Every advance made by printing had as its motive [the expansion of] religion." The first printing was sacred literature or sacred art. China printed "Buddhist pictures and texts" and Japan printed "to the highest stage of perfection [only] Buddhist sacred literature" for six centuries. To the Mongol conquest, "printed literature [was] almost exclusively religious." The Han Empire broke up at the beginning of the $3^{\text {rd }}$ century and during 400 years of war the conservative Confucianism lost to Buddhism. "The age of anarchy was also an age of faith." Buddhism brought new life to Chinese art and in the T'ang dynasty, "Chinese

26. Kroeber, 1944, p. 209, 416, 418, 453, 685.

27. Ibid, p. 191-192.

28. Carter, 1925, p. 11-15. 
art entered its greatest creative period." Religion brought art, and "religion and art [brought] the impulse to [printing]."

The "separate symbols" of China meant that "block printing [became] the truly significant form." Fêng Tao improved block printing, which made for "quantity production [and] produced China's finest books." ${ }^{29}$ His classics "ushered in the Renaissance." Blocks were made of pear wood. The plate "was squared to the shape and dimensions of two pages." The surface was rubbed with paste, and pages of "thin transparent paper" were placed on the block "in an inverted position, the thinness of the paper [showing] writing through [from] the back." When the paper was "rubbed off," a clear impression in ink of the reversed writing was left on the wood. The workman cut away the wooden surface not covered by ink and left the "characters in relief." The face of the characters was inked and the "paper laid on the block. One man [could] take off [2000] copies in a day." 30

Buddhist lore gave "the art of printing" to the world. Buddhist monasteries elaborated devices for "the reduplication of sacred books and texts." The "small stamped figures of Buddha [marked] the transition from the seal impression to the woodcut." When the stamp was turned upside down and paper laid on it and rubbed with a brush, "the way was [opened] for making impressions of any size desired, and for [the] improvement of technique. [...] Rubbing from stone, printed silk, stencil, seal, and stamp [led to] the block print." China's cultural achievement reached its peak probably under Ming Huang (712-756). ${ }^{31}$

The first printed book has been dated to 868 and "consists of [6] sheets of text and [a] shorter sheet with a woodcut pasted together to form a continuous role of 16 feet." "Single-page block prints" developed more rapidly than books. The use of rolls probably continued to the end of the T'ang dynasty, when under the influence of printing, paged books appeared. Chinese printing "was confined to non-canonical works" or cheap books for "the ignorant and poor. [...] The Confucian historians, [with] a contempt for the monasteries," prepared the way for "the printing of the Confucian Classics. [...] As late as 932, [printing] was confined to two localities" in China. ${ }^{32}$

Non-Buddhist printing first began at C'heng-tu in Szechuan and it is probable that the first official printing of books and paper money began in this province. It secured its independence in 907 and engraved a "corrected text of

29. Ibid. p. 17-19, 23-24.

3o. Ibid., p. 23-27, 54.

31. Ibid., p. 29-32.

32. Ibid., p. 41-42, 44-46. 
[classics] on stone, [a] rapid advance of printing from wooden blocks." The work of printing and editing 130 volumes lasted from 932 to 953. Printing was designed to authenticate the text and "private printing of the classics" was prohibited until 1064. The classics restored Confucianism and "a classical renaissance followed" in large-scale public and private printing under the Sung dynasty after 960.33

\section{THE SPREAD OF BLOCK PRINTING}

A mixture of race, language and religion, and "a high valuation of literature and art" stimulated block printing in Turfan. Competition developed between "the roll, the folded book, and the Indian pothi." ${ }^{34}$ Documents spared as a result of religious considerations in ruined temples and monasteries show better printing and better preservation in the $13^{\text {th }}$ and early $14^{\text {th }}$ centuries. While Buddhists were concerned with repetition and reduplication, Mohammedans were opposed to printing, though favourable to the spread of paper. Tabriz was apparently the only centre "in the Islamic world [with] a clear record of block printing [in the] issue of paper money" in 1294. Block printing probably entered the European world from China "through Europeans in China, Persia or Egypt during the Mongol Empire," which extended from Europe to China in the early part of the $13^{\text {th }}$ century and included Russia after 1236-40. Roman Catholic missionaries were in China after 1294. During the Crusades, block printing developed in Egypt. Christian traditions and illiteracy meant that texts of the Bible and pictures displaced texts of the Koran. ${ }^{35}$

Sheet dice or playing cards appeared in China as early as 969 A.D. In Europe, "the transition from dice to cards" possibly accompanied the shift "from manuscript rolls to paged books." Printing produced pages for books and cards for dice. References to card printing in Europe appeared in Germany and Spain in 1377, Luxembourg and Italy in 1379, and France in 1392. An edict against card-playing was passed in Paris in $1397 .{ }^{36}$ The card-printing industry became important in Venice and Germany after 1400. "The earliest religious block prints" appeared in the last decades of the $14^{\text {th }}$ century in southern Germany and Venice. They included "scenes from the Bible [or pictures] of Saints, [which were] printed in outline [and] filled in by hand or stencil [with] crude workmanship." Image prints without texts were followed by those with texts. Pictures and texts were made into

33. Ibid., p. 48, 52, 55-56.

34. Ibid., p. 103-104, 108.

35. Ibid., p. 119, 122, 128, 132, 138.

36. Carter, 1925, p. 140-141. 
books with "blank pages folded together." European and Chinese block prints appeared only on one side of the paper. The demand suggested an "awakening intellectual life," the existence of paper as a "strong inexpensive material" and an impulse from China. Seal-cutting and textile-printing were also important developments. "Egypt and Babylon had [used] wooden blocks to stamp bricks; Rome had used dies for coins, seals for wax and metal letters for branding cattle and slaves." ${ }^{37}$

Cotton-and probably textile-printing-came from India. The earliest printed fabrics appeared in Egypt in the $6^{\text {th }}$ century. They appeared in Germany in the $12^{\text {th }}$ and $13^{\text {th }}$ centuries and expanded rapidly in the $14^{\text {th }}$ century. Textile printers were concerned with ornamentation and probably paved the way for paper block-printing with the emphasis on edification in piety. Few textile prints had a religious motive. ${ }^{38}$

\section{EARLY FORMS OF MOVABLE TYPE}

The invention of moveable type followed. Moveable type was made of baked clay from 1041 to 1049 and this was followed by tin and wood. Moveable type reduced the long delays involved in cutting wooden blocks with great outlay of labour and material. Type was cut, sawed, finished and put in a revolving table for the type setter. It was set in a form and ink applied in preparation for printing. Pieces were made to "fit together in a perfectly even and rigid block [and] [s]ystematization and mechanical arrangement" of the script symbols were necessary for typesetting. "The type mould [and] metal type [were] perfected in China or Korea." 39 "In 1314 a library of 10,800 books" was taken from Nanking to Korea and to this "the Mongol emperor added 4070 volumes." In 1392, a type foundry was started and in 1403, metal type was regarded as a great invention. "A second font of type was cast in 1420 " with more convenient pieces making it possible to print "twenty sheets a day." A font of larger type was cast in 1434 and other fonts in 1455,1465 and 1484 .

The Koreans developed the type mould. Wooden blocks were pressed in the sand and type was cast from the negative moulds with the pouring in of melted bronze. "Metal type spread to China." ${ }^{10}$ The first book produced from moveable type appeared in Japan in 1596 , but Japanese printing was done with wooden

37. Ibid., p. 144-145, 151-155.

38. Ibid., p. 146, 148-149, 154.

39. Ibid., p. 160-166.

4o. Ibid., p. 169, 173, 177. 
blocks after 1629. Type printing was stopped in Korea in 1544. Printing from metal type required large capital and was prosecuted almost entirely by governments, which proceeded on the principle that "whoever is desirous of governing must have a wide acquaintance with the laws and the classics." ${ }^{\prime 11}$

"Block printing was more practical for private and commercial purposes." ${ }^{\text {"2 }}$ Block printing prevailed in China and the Far East because of the character of the script. The "printing of dynastic histories" was started at the end of the $10^{\text {th }}$ century and completed by the National Academy over a period of nearly 70 years. Compilation of the Taoist canon was completed in 1016 and the "records and annals of the first and second Han Dynasties" were printed from 990 to 994. "Printed books [were] more numerous [and] scholars ceased to make [collections]" a subject of first importance. With scarcity of copper, merchants "[deposited] cash with the government [in exchange for] certificates of indebtedness" about 807 .

In Szechuan, the first state paper money was printed about 935 to 954. The government started an office for "convenient money" at Si-an-fu and 1,7 million tiao were in circulation by 998. An additional 1,13 million were issued by 1022 and circulation was limited to $1,256,340$ tiao in $1032 .{ }^{43}$ Inflation appeared from 1094 to 1107 and "high prices and falling currency" characterized the $12^{\text {th }}$ century. The Kins controlled the northern government and after 1156, issued paper money and inflation was pronounced from 1161 to 1165 .

In the Mongol empire, "paper money became a permanent feature of financial policy" after 126o. A treasury was established in each province for the issue of paper money in 1264. Under the Mongols, 37 million separate notes were printed annually, but depreciation was not as marked as in the previous century. From 1368 to 1399 , paper money issues declined and ceased before $1425 .{ }^{44}$

Private printing increased in importance in "classics, commentaries, and histories." The sacredness of the printed page "prevented the printing of any books not considered of great worth and dignity [but] local histories [were followed by books] on botany and agriculture and poetry." In Fukien, printers of the same name extended over four centuries. After the conquest of southern China by the Mongols in 1280, the scope of printing was extended to medicine and

41. King to his attendants, quoted in Ibid., p. 171.

42. Ibid., p. 178 .

43. Ibid., p. 57, 67, 69-72.

44. Ibid., p. 73-76. 
almanacs. The quantity of printed material reached its peak in the early years of the $15^{\text {th }}$ century.

Official printing under the Mongols was carried out at the "government printing office" established in Cambaluc in 1236. The Buddhist canon of 1521 separate works involved over 5000 volumes of 130,000 pages or 130,000 blocks. It "was reprinted twenty times." "Bu "Buddhist printing spread to Korea" by 950 and in 989 , in Korea, a copy of the canon was secured, revised, and reprinted over sixteen years. In Japan, the seal also preceded the block print, but about 770 , the Empress Shôtoku ordered one million copies of Buddhist prints as charms. A copy of the Buddhist canon was taken to Japan in 987. "With the Ashikaga régime in Japan [beginning in 1336] and the expulsion of the Mongols from China [in 1368]," the second wave of Chinese culture swept over Japan. The Chinese classics were printed in Japan after 1350. "The first original Japanese work" in print appeared at the end of the $16^{\text {th }}$ century. Paper currency was issued in Japan from 1319 to $1327 .^{46}$

\section{CHINESE LANGUAGE AND WRITING}

The Chinese language has been described as in one respect having "the very lowest grade of structure and poverty of resource [but] the most remarkable example of a weak instrumentality [as a] means of accomplishing great things." It has been a result of phonetic decay. Each character is a whole word and no alphabet exists. With only about 1500 words, it has grown by "differentiation of meaning" and tone of utterance..$^{47}$ It is the "only language in which pictographs survive, but the great majority [of characters] are phonetic." The language is "terse, concise, with short words and short sentences."

A common dictionary was developed about 100 in Han times with the "classification of characters according to radicals [or] common ideographic elements." A pronouncing dictionary with reference to the "phonetic quality of spoken words" followed, possibly as a result of knowledge of Indian writing introduced with Buddhism. Government recognition of Buddhism for two centuries was accompanied by intense activity of "sects, philosophy and propaganda." In China, phonetics was the "core of its philology, owing to the near-lack of

45. Ibid., p. 58, 6o-63.

46. Ibid., p. 34-35, 53, 57-58, 64, 77 .

47. William Dwight Whitney, The Life and Growth of Language, London, Henry S. King \& Co., 1875, p. 111, 237-238.

48. Thorndike, 1927, p. $245,248$. 
[a] formal grammar, "whereas in most languages it was a "gateway to structure."49 Chinese characters were current "throughout the empire" and were "written and understood by the literate."

"The script [provided] a means of communication between [those unable to] understand each other's [dialects]. [...] The Japanese invented a syllabary, [but used] an immense number of Chinese words." 50 "By its persistency, the Chinese language maintained its own institutions-political, religious, and linguisticsubstantially unchanged." ${ }^{51}$ Its implications for printing were obvious through their impact on the growth of a learned class and their limited influence on public opinion. Spring and autumn annals were in evidence from the $8^{\text {th }}$ century B.C. and as an official gathering of news for the benefit of the rulers, they were kept by the court historians.

\section{NEWS}

"Private written newsletters" were circulated in the Han Dynasty (206 B.C.220 A.D.), following its elaboration of a "system of military roads and post relays." The system of "metropolitan representatives" was highly developed in the T'ang Dynasty (618-907) and was inseparably linked to the rise of the "official gazette." A Bureau of Official Reports was set up and "continued in the Sung Dynasty" in the $10^{\text {th }}$ to $12^{\text {th }}$ centuries at Sain. It became "an important system of publishing news periodically" in a gazette, which had "a large circulation among scholars," particularly in the Sung Dynasty. Other papers were added, including a kind of "tabloid news." A petition for its suppression in 1160 A.D. marked the "[beginning] of censorship." The earliest newsletters were sent by representatives of provincial officials residing at the capital to organs in the country and were circulated in manuscript form, even to the $19^{\text {th }}$ century. Written transcripts were preferred to inferior printing from clay blocks. The official gazettes included references to doings of the Imperial Court, official edicts and orders, and memoranda by ministers and provincial authorities. Semi-official gazettes were later published by commercial firms. Since the readers were chiefly the gentry and the mandarinate, they determined the character of news. The gazettes were a press service for official bureaucrats. ${ }^{52}$

49. Kroeber, 1944, p. 224.

50. Woolner, 1938, p. 71-72.

51. Whitney, 1888, p. 240.

52. Yutang Lin, A History of the Press and Public Opinion in China, Chicago, University of Chicago Press, 1936, p. 11-15, 17-18. 


\section{PUBLIC OPINION AND EDUCATION}

The spoken press was "born in song," and ballads were effective weapons of public criticism, being reflections of public opinion rather than news. They were much used in the first organized movement of public criticism. Rulers were satirized after death as a means of having a "deterrent effect" on rulers who were living. The Chinese were "consistently and thoroughly cynical about most of their officials all the time."

In the later Han Dynasty, Confucianism was revived and public criticism became fashionable and powerful. Confucian morality favoured a very "high code of personal conduct" and the civil service encouraged a "high code of moral conduct." The Imperial University had an enrolment of 30,000 students, chiefly candidates for government offices. The short life of many rulers of the later Han dynasty enhanced the importance of Empress Dowager and eunuchs, and excited the indignation of scholars with sex and class prejudices..$^{53}$ War "between the scholars and the eunuchs" broke out from 126-144 and particularly from 147-189.

"The first student movement" developed in 153, in which the government was criticized in "ballads, joint petitions and official impeachments" incidental to the power of those who held offices. Drastic repression began in 165 and the movement failed through the lack of any notion of personal civil rights. With the "absence of constitutional protection," public indifference to national affairs followed the massacres, persecutions and exiles of the inquisition of the Later Han Dynasty. "Taoism came into fashion" at the "fall of the Later Han Dynasty" and the "first romantic movement" followed its interest in pure conjunctures. ${ }^{54}$

Invasion of the barbarians towards the end of the Ch' in dynasty and national weakness accompanied the disappearance of public opinion. Student movements emerged as a result of the denial of normal outlets of opinion. In the Sung Dynasty, the student movement of 1109 drew up petitions which had the support of public opinion. But it degenerated "into petty politics" and the force of the movement was checked by the government. ${ }^{55}$

During the T'ang and Sung Dynasties, the "polished essay" was introduced "as a test for office holding, [and] the official class and literati became practically identical." It was described as "a clever contrivance adopted by a former dynasty

53. Ibid., p. 20, 24, 30-33, 36.

54. Ibid., p. 35, 37, 39, 40-41.

55. Ibid., p. 45-46, 48, 57 . 
to prevent the literati from thinking too much." ${ }^{56}$ This became a prelude to the Mongol invasion.

In 1594, Ku "began to lecture at Tunglin College" and started "a great movement [for] political criticism." Again the eunuchs introduced most severe measures of persecution of scholars. A "[normal] established force of public opinion" was impossible without "constitutional protection" for scholars and writers. Public criticism was limited by literacy, but "among the educated class in times of national crisis [it] burst forth" in an "organized articulate" fashion, which informed and guided public opinion. ${ }^{57}$ In the history of the struggle between public opinion and authority, in which "the people may be allowed to act, but may not be allowed to know," 58 scholars were pitched against eunuchs and lost. ${ }^{59}$ The means of communication were not sufficiently developed to encourage effective criticism, and periods of prosperity were followed by the growth of public opinion in limited areas, by its suppression, and by the corruption of bureaucracy and collapse in the face of barbarian invasion.

\section{CULTURE AND IDEOLOGY}

G. Lowes Dickinson emphasized the contrast between Chinese civilization and Western civilization in his Letters from John Chinaman. Confucius discouraged "preoccupation with the supernatural." Though Buddhism and Taoism lent themselves to "practices and beliefs," Confucian philosophy emphasized a moral order. The governing classes were set apart for the "pursuit of [the] liberal arts" and were open to anyone with "the requisite talent and inclination." The "poets and literary men looked for good not in wealth [or] power [or] miscellaneous activity, but in a trained choice and exquisite appreciation of the most simple and universal relations of life." The Chinese were always members of a "family group" believing in "brotherhood and the dignity of labour."

Western civilization grafted morality onto economic relations and economic chaos was the result. The English citizen was "divorced from Nature, but unreclaimed by Art; instructed, but not educated; assimilative, but incapable of thought. [His] literature is the daily press, with its stream of solemn fatuity,

56. Thorndike, 1927, p. 266-267.

57. Lin, 1936, p. 5, 29, 68.

58. Confucius, quoted in Ibid., p. 3 .

59. Ibid, p. 2-3, 5-6.

6o. Goldsworthy Lowes Dickinson, Letters from John Chinaman and Other Essays, London, George Allen \& Unwin Ltd., 1948, p. 32, 41-42, 45. 
anecdotes, puzzles, puns, and police-court scandal. [...] The function of government [was] so important and so ubiquitous that you can hardly realize the condition of a people that is able almost wholly to dispense with it," but English elections meant not "representation of the people," but of interests. The Christianity of Europe meant "not labour on earth, but contemplation in heaven, not unity of the human race, but communion of saints." ${ }^{\prime 1}$

Buddha discovered "the want of permanence in the world of phenomena" and regarded the whole world as one of change. Buddhism opposed the sensualism and "ascetic extremes of Brahmanism," which "held life [to be] an evil, from which it was the object of the higher knowledge to deliver its possessor." ${ }^{\text {" }}$ The Chinese system has been described as having "one of the greatest and most influential doctrines of ethical conduct the world has ever known. For the individual, virtue is its own reward." Family relations came first in "the practice of benevolence. [...] The Chinese masters inculcated profound truths [but] laid them down dogmatically [with] little attempt at rational proof." The "rules of propriety," and the "crust of Chinese formalism" checked a rich "spiritual growth." ${ }^{3}$

The Confucian idea emphasized public service and the bureaucracy broke up literary coteries. Chinese literature reflected the intensity of high status and successful careers depended on literary training. The importance of the examination system meant modelling on "classic and canonical works in prose and verse." The drama and the novel, encouraged in the Mongol period, "[aimed] to please" and were addressed to the ear and were "written in more or less colloquial or vernacular language" outside the fixed tradition. The drama was in spoken, instead of the classical written Chinese. The "true Chinese literature [was] written and [read] by the eye." Poetry with "meter and rhyme" was part of the true Chinese literature. "Belletristic prose, letters, memorials, exegesis, criticism, informational works and compendia [were] written in [the] classical language and style [of] scholars." Shen-Yo (441-513) was responsible for the discovery of tones. Philosophy was near literature in China as it had an "ethical and human," rather than a "metaphysical or logical, bent."

61. Ibid., p. 24-25, 34, 39, 46 .

62. L. T. Hobhouse, Morals in Evolution: A Study in Comparative Ethics, $5^{\text {th }}$ ed., New York, Henry Holt \& Company, includes Preface to $4^{\text {th }}$ ed., 1923, p. 477-479.

63. Ibid., p. 528, 533, 538-539, 544 .

64. Kroeber, 1944, p. 224-225, 455-456, 461. See also Shryock, 1932, p. 165-166. 


\section{LITERATURE AND EDUCATION}

Japanese literature was aristocratic and used suggestion through "hints, indirections and intangibles." Poetry excluded the use of Chinese loan words and reflected "a persistent attitude of national exclusiveness." It operated "in a restricted field with restricted techniques and accented limitation." About 900 prose works became private and secular. An "avowed literature" emerged with the tale or story developing into the novel and historical narrative. By 950, women were writing most of the best prose with subtlety, refinement, indirection and subjectivism. Around 1100, the historical romance crowded out the personal novel and diary. After 1600 , peace, prosperity and control of the middle classes brought a vulgar literature. From 700 to 1600 , literature belonged to a restricted, over-cultivated class and from 1700-1800, it became non-aristocratic in the drama and the novel of popular appeal, but had no great control of form. "In China and Japan, conscious literature was essentially [the] product of [a] class" - the classical scholars and the aristocracy. After cultural creativeness of the class had withered in the literature of the upper stratum, popular efforts came to the surface. In China and Japan, the major dramatic development did not coincide in time and place with the major literacy developments, as was the case in other countries. ${ }^{65}$

"The worship of ancestors" was apparently taught in China as early as 2000 B.C. It was reduced, by Confucius, "to a definite system of ceremonial ethics. [...] Chinese life [became a] continuous ceremony [and emotions were] cultivated and maintained [by] prescribed ceremony or etiquette. [...] The early feudal system of China [was] overthrown in 225 B.C. by the Ch'in (T'sin) Dynasty [and] the emperor gave [an order] to destroy all the literature of the past." ${ }^{\prime 66}$ Books were burned and ordered suppressed in 213 B.C. ${ }^{67}$ Under the Han dynasty, "ancestral worship" and the "old classics" returned, "but the feudal system [had been] overthrown. [...] Emperor worship [bridged the gap between] ancestor worship and the official group. [...] Ancestral culture [united] the district to its governor" and the governors were united "in the service of the empire." China was "a federation of districts ready to fall apart [with] disturbance [to] imperial culture.[...] The ancestral culture had great emotional force" in local groups, but the culture connecting large groups was weak, "and the imperial culture was weakest of all. The ancestral culture was basic in Chinese civilization." 68

65. Ibid., p. 444, 468, 470-471, 473-474.

66. Denison, 1928, p. 104-105, 107-108.

67. Shryock, 1932, p. 22.

68. Denison, 1928, p. 108, 111, 113, 115. 
In contrast with India, where "Vedic education rested [on] oral [tradition]" and in which the abhorrence peculiar to "guilds of professional magicians" of "fixing tradition in writing" was shared, the literati in China depended for prestige on "a knowledge of writing and literature." They apparently emerged in the feudal period from "families [with a] knowledge of writing whose social position [depended on] writing and literature." In the struggle between the "prince [and] the feudal powers," the literati apparently became associated with the "pontifical Cesaro-papist character of imperial power. [...] Literary education and subordination under a pontifex," destroyed the possibilities of a caste system. The Chinese literati-politicians were trained in ritual and concerned with problems of internal administration. Their position differed from that of the educated layman of Greece. In the Confucian period (Confucius died 478 B.C.), "great families' were in possession of power." In the Han dynasty, "the bestowal of offices according to merit was raised to the level of a principle [and] in the Tang dynasty [69o A.D.] regulations [were] set up for the highest degree" and colleges were established for the training of the literati. Education became a force used by the central authority of the prince to prevent "the formation of a closed estate, which would have monopolized the rights to the office prebends." Education was purely secular, but bound to the orthodox interpretations of classic authors. "It was a highly exclusive and bookish literary education." Like all education established by priesthoods, it was "non-military and purely literary. [...] Because of the peculiarity of the Chinese [script] and, [in turn] of literary art," the literary or "written character [of education] was pushed to extremes. [...] Examinations tested whether the mind was steeped in literature and whether the candidate had ways of thought suitable to a cultured man. [...] The educated stratum of China [was one of] officials and aspirants to office." ${ }^{\prime 9}$

In India, Judaism, Christianity and Islam-"the literary character of education"-was a result of the dominance of Brahmans and "Rabbis trained in literature, or of clerks and monks of book religions professionally trained in literature. [...] During the Middle Ages, the military education of the knight, and the education of the salon, provided a supplement to education transmitted by books, priests and monks, but in Judaism [and] in China, this supplement was absent. [...] In India and China, the literary means of education consisted of hymns, epic tales, and casuistry" in ritual education, but in India "cosmogonic, religious and philosophical speculations" were in evidence, whereas in

69. Max Weber, From Max Weber: Essays in Sociology, Hans Heinrich Gerth and C. Wright Mills (eds.), New York, Oxford University Press, 1946, p. 417, 419, 423-424, 427-428. 
China speculations were limited to "rational systems of ethics. [...] The principle of strictly oral tradition has almost everywhere applied only to charismatic revelations and to charismatic commentaries of these, and not to poetry and didactics." ${ }^{70}$

\section{CONTRASTING EASTERN AND WESTERN CIVILIZATION}

In the Mediterranean, trade had brought a rationalization of pictorial characters into the alphabet, but in China the pictorial script assumed a "literary product addressed to the eyes and the ears," particularly the eyes. "The visual character was remote from the spoken word." A "monosyllabic language" required the perception of sound and of the "pitched tone. Its sober brevity and syntactical logic" stood in sharp contrast with the "visual character of script." As a result of the "very rational qualities of its structure," the Chinese language was not adapted "to poetry or to systematic thinking [or to the] oratorical arts of the Hellenic, Latin, French, German and Russian languages." The limited stock "of monosyllabic words," as contrasted with the rich stock of "written symbols," emphasized the "poor and formalistic intellectualism of the spoken word." The art of script meant an emphasis on reading and writing. Speech remained with the people. In contrast, Hellenism emphasized conversation and dialogue. In China, speech played little part in official literature. "Speech, as a rational means [of] attaining political and forensic effects" as used by the Greeks, "could not be developed in a bureaucratic patrimonial state [with] no formalized justice. Chinese justice [was] in part a summary Star Chamber procedure and, in part, relied solely on documents."

Chinese thought was hampered by "the pictorial and the descriptive. The power of defining and reasoning" was not available to the Chinese. A "purely scriptural education detached thought from gesture and expressive movement. The pupil learned to paint about 2000 characters." A "training in calculation" was lacking in "Chinese education" and was acquired by merchants in their business affairs.

In Christianity, Islam and Hinduism, education was bound by sacred or cultic scriptures. "Only the Hellenic philosophers' schools engaged in an education solely of laymen and freed from all ties to scriptures, freed from all direct interest in prebends, and solely devoted to the education of Hellenic 'gentlemen'." Chinese education was concerned with prebends and "tied to a script, but it was purely lay education, partly ritualistic and ceremonial, partly traditionalist and

70. Ibid., p. 428-429, 463 . 
ethical." Unlike "Occidental jurisprudence," it had no "rational-formalist character." Unlike "Rabbinic, Islamite and, partly, Indian philosophy, [...] it was not an empirical casuist character" and unlike "the philosophies of the Occident and the [Middle] East, based on Hellenist thought," Chinese philosophy produced no scholasticism. "Chinese philosophy bound to script, was concerned with purely practical problems [and the interest] of the patrimonial bureaucracy." ${ }^{71}$

\section{THE SPREAD OF PAPERMAKING}

The use of paper money in China stimulated trade to the West. Silk had been carried from China to Rome and Justinian had reopened the silk route from 527-565 A.D. ${ }^{72}$ A century after Justinian, the "Arabs supplied Europe with silk [brought] from China through Samarkand." Paper production probably reached Turkestan by 200 A.D. Turfan was an important cultural centre in Chinese Turkestan and paper was manufactured there by 399. Workmen were brought to Tibet to manufacture paper and ink in 648 A.D. ${ }^{73}$ After the capture of Turkestan by the Arabs in 751 , paper manufacture began in the West. ${ }^{74}$ The Mohammedans had then a monopoly of paper and papyrus. Prohibited from using pig skins for parchment, they were reluctant to use any animal skins because of the difficulties of detection. Consequently, they concentrated on paper. The caliphate under the Abbassides was moved to Baghdad, which became a refuge for science and letters. The intellectual and natural splendour described in the Arabian Nights reflected the prosperity of Haroun al-Rashid (786-809) in Baghdad. The introduction of paper coincided with the outburst of the period. By 793-794, Chinese workmen had been brought to make paper at Baghdad and its production was encouraged. In a country deprived of paper mullbery trees, they began to use rags.

Another centre was established at Tihama ${ }^{75}$ and Damascus became an important export centre. ${ }^{76}$ Egyptian writers favoured papyrus over paper in the $9^{\text {th }}$ century, but in the second half of the century, paper had become a commodity of luxury for writing. The use of paper spread rapidly in the $10^{\text {th }}$ century and

71. Ibid., p. 430-433.

72. Frederick J. Teggart, Rome and China: A Study of Correlations in Historical Events, Berkeley, University of California Press, 1939.

73. Carter, 1925, p. 86-87, 96, 103.

74. Douglas Crawford McMurtrie, The Book: The Story of Printing E Bookmaking, New York, Covici Friede, 1938, p. 64.

75. Blanchet, 1900, p. 26, 28-29, 33.

76. Carter, 1925 , p. 98. 
by 1035 it was available in large quantities at low prices. Papyrus was steadily displaced to 936 and by the $11^{\text {th }}$ century, paper replaced rolls of Egyptians papyrus. ${ }^{77}$ Apparently, parchment did not entirely supersede papyrus until the latter was abandoned by Pope Benedict VIII (1020-22). Paper was made from linen rags or flax ${ }^{78}$ and sizing was obtained from "wheat starch." At the end of the $13^{\text {th }}$ century or the beginning of the $14^{\text {th }}$, animal glue replaced the starch. After the $15^{\text {th }}$ century, much shorter fibres were used. ${ }^{79}$

The earliest paper document in Europe was a deed in Sicily dated 1109. ${ }^{80}$ Under the Arabs, paper was manufactured in large quantities at Fez. From 1184 to 1213, 400 paper mills were counted at Fez. Hydraulic power had been introduced to replace manual labour. Paper was in use in Spain by 1120. The imposition of a tax suggested that paper was available in abundance at the beginning of the $13^{\text {th }}$ century.

In 1145, Roger II of Sicily ordered government documents written on paper to be copied on parchment. By the $12^{\text {th }}$ century, the opposition of Europeans had been overcome, though paper from Africa imported through Sicily was prohibited for public documents by Frederick II in $1221 .{ }^{81} \mathrm{~A}$ paper mill was in existence at Jativa near Valencia in Spain by 1150, Fabriano in Italy in 1276, Bologna in 1293, Troyes in France in 1348, Nuremberg in 1390 and Huy in Flanders in $1405 .{ }^{.2}$ In a 1273 decree, James I of Aragon confirmed the Jews' privileges concerning the manufacturing of paper with regulated taxation at 3 deniers per ream. ${ }^{83}$ Peter III of Aragon gave special privileges to papermakers at Jativa in 1280 , in return for the payment of two deniers and one obole of Valence for each ream "en plus du droit que l'on a coutume de payer à Jativa" and at Valencia "en sus du droit

77. Blanchet, 1900, p. 29, 31-32.

78. Carter, 1925, p. 97.

79. Blanchet, 1900, p. 34-36.

8o. Carter, 1925, p. 100.

81. Blanchet, 1900, p. 46, 50, 59 .

82. André Blum, On the Origin of Paper, trans. Harry Miller Lydenberg, New York, R.R. Bowlier Company, 1934, p. 32-33. See also André Blum, "Les premières fabriques de papier en Occident," Académie des Inscriptions et Belles-Lettres, Comptes-rendus des séances de l'année, 1932, p. 102-113. The manufacture of paper spread from Jativa to Girone, as paper was sold by Jewish merchants from Catalonia to the Midi, from Perpignan, Narbonne, Montpelier, Troyes and Essenes to Nuremberg.

83. James I of Aragon, "Derechos Reales impuestos a los judios que en Xativa fabricaban papel" ("Redevances royales imposées aux Juifs qui fabriquent le papier à Xativa"), February 8, 1273, quoted in Blanchet, 1900, p. 50-51. 
déjà établi dans cette ville vous Nous payerez douze deniers réaux par chaque boite que vous porterez à ladite ville, acquittant les droits du Marché public." ${ }^{84}$ Mohammedans were not to be used to start new factories, but Christian workers, who had learned the trade under Arabic masters, were expected to learn the art. Unfortunately, the traditions of good papermaking at Jativa and Valencia had declined by 1338 . The suppression of block printing in Spain lowered the price of rags and great quantities were exported to Genoa from the north of Spain in return for paper. This trade apparently reached 500,000 piastres in 1720 . At the beginning of the $19^{\text {th }}$ century, over 200 mills were operating in Spain. ${ }^{85}$ Paper was used extensively in Spain in the $12^{\text {th }}$ century, but its price was high as late as 1415 . Shipments of paper from Genoa to Bruges were noted in 1379. In the $14^{\text {th }}$ century, Italy surpassed Spain and Damascus and at the end of the century, Germany purchased paper from Venice, Milan and France. ${ }^{86}$

There was a rapid increase in the production of paper in Europe in the $14^{\text {th }}$ century. Paper's spread was handicapped by its fragile character, prejudice against its "Judeo-Arabic origin" and the opposition of parchment makers and its high price as an imported product. Few could read, and the demand for a cheap writing material was small. On the other hand, "its greater flexibility and [its] lower price," as a result of its manufacture from linen rags, since linen clothing was being substituted for woolen clothing especially in the $15^{\text {th }}$ century, gave important advantages. By the end of the $14^{\text {th }}$ century, Italy exported paper at a price one-sixth that of parchment. An "ordinance in Genoa protected the rag industry and made paper makers dependent on rag merchants," ${ }^{\prime 87}$ but in 1481 paper-makers were allowed to form a corporation. ${ }^{88}$

Towards the end of the $17^{\text {th }}$ century, Germany shifted its purchases to the Tyrol and Genoese areas, while the French invaded the markets of the Orient with serious results in Venice. The paper-makers petitioned for their exemption from import duties on raw materials. The plague compelled inhabitants of Marseilles and the Provence to burn their rags, and mills in France were stopped with the result that the time was opportune for the purchase of rags across towns in Turkey and Syria. At this date, there were 190 cuves in Venice and $3^{8}$ plants were without work. Papier fin and papier gris were sent to the markets of the East

84. Peter III of Aragon, "Pro Papiro Xative” ("Pour le papier de Xativa”), January 18, 1281, quoted in Ibid., p. 52-54.

85. Ibid., p. 51, 53-54, 56-57, 59, 100.

86. Carter, 1925, p. 101.

87. Blum, 1934, p. 34-38.

88. Ibid., p. 169-171, 173-178. 
and the West. In the $18^{\text {th }}$ century, rags were generally scarce and in 1762 , the sale of rags beyond the borders of the Duchy of Parma was only permitted after the local demand had been satisfied. ${ }^{89}$

\section{PAPER MANUFACTURING IN EUROPE}

The development of writing on a large scale assumed the existence of material cheaper than parchment, which was very expensive until late in the $13^{\text {th }}$ century. Businessmen scraped old manuscripts and then used the fresh surface for keeping accounts. Palimpsests were used on an extensive scale two centuries before the introduction of printing. By the second half of the $13^{\text {th }}$ century, Italians were engaged in the manufacture of paper and succeeded in improving its quality over that from the Orient by making it suitable for writing and resistant to humidity. From 1300 to 1450, Italy had almost the monopoly of paper production in Europe. The Venetian senate prohibited the export of rags to places other than Treviso in 1366 and from Venice in 1373. The earliest known watermark (filigrane) in 1282 suggested that by that date Italian mills were concerned with wider markets. ${ }^{90}$

Although Spain was apparently an early centre for the manufacture of paper, "books and playing cards" appeared late at the great Spanish fairs. They were "an important export in the $16^{\text {th }}$ century." ${ }^{\text {91 }}$ Paper, probably from Spain, appeared among the documents of French archives about 1250 and Italian filigranes became conspicuous after 1300 , especially after $1315 .{ }^{92}$ Prices of paper in 1343 were high. France had imported paper from Spain and the oldest known French mills were dated 1348 . French paper manufacturers were exempt from taxation, as were the book dealers in the early period. The increase in demand for paper and the difficulties of importing from Italy led to the search for suitable sites in France. Large paper merchants leased flour or textile mills and converted them

89. Blanchet, 1900, p. 66-68.

9o. Blum, 1934, p. 36, 45 .

91. Abbot Payson Usher, The Early History of Deposit Banking in Mediterranean Europe, Cambridge, Massachussetts, Harvard University Press, 1943, p. 128.

92. The oldest known English paper, dated from about 1282, was probably Spanish and introduced from Bordeaux when England had control of Aquetaine. Thorold Rogers stated that he saw paper dated 1335, "certainly the rudest in manufacture." In Thorold Rogers, The Economic Interpretation of History, New York, G.P. Putnam's Sons, 1888, p. 280. See also Alexandre Nicolaï, Histoire des moulins à papier du sud-ouest de la France 1300-180o: Périgord, Agenais, Angoumois, Soule, Béarn, Bordeaux, G. Delmas, 1935, p. xvi, xviii. 
into paper mills as a means of avoiding the cost of transport from Italy, impositions on Italian trade and the delays incidental to dependence on the fairs. ${ }^{93}$

The paper industry obtained a substantial footing in Italy in the $13^{\text {th }}$ century, in France in the $14^{\text {th }}$ century, and in Germany in the $15^{\text {th }}$ century. Paper was introduced generally in the $14^{\text {th }}$ century, but it did not become a serious rival for parchment until the $15^{\text {th }}$ century. 
